\title{
Fifty Years of the Korean Journal of Clinical Laboratory Science: About Name and KCl Registration
}

\author{
Bon-Kyeong Koo ${ }^{1}$, Ho Joong Sung ${ }^{2}$, Ki-Jong Rhee ${ }^{3}$, Byoung-Seon Yang ${ }^{4}$, Sei Ick Joo ${ }^{5}$, \\ Seung-Gu Choi ${ }^{6}$, In-Ho Jang ${ }^{7}$, Man-Gil Yang ${ }^{8}$ \\ ${ }^{1}$ Department of Laboratory Medicine, Samsung Medical Center, Seoul, Korea \\ ${ }^{2}$ Department of Biomedical Laboratory Science, Eulji University, Seongnam, Korea \\ ${ }^{3}$ Department of Biomedical Laboratory Science, College of Health Science, Yonsei University, Wonju, Korea \\ ${ }^{4}$ Department of Medical Laboratory Science, Jinju Health College, Jinju, Korea \\ ${ }^{5}$ Department of Biomedical Laboratory Science, Daejeon University, Daejeon, Korea \\ ${ }^{6}$ Department of Biomedical Laboratory Science, Shinhan University, Uijeongbu, Korea \\ ${ }^{7}$ Department of Biomedical Laboratory Science, Sangji University, Wonju, Korea \\ ${ }^{8}$ Department of Research and Experiment, Seoul National University Hospital Biomedical Research Institute, Seoul, Korea
}

\section{대한임상검사과학회지 50년사: 명칭과 $\mathrm{KCI}$ 등재에 대하여}

\author{
구본경 $^{1}$, 성호중 $^{2}$, 이기종 ${ }^{3}$, 양병선 $^{4}$, 주세익 ${ }^{5}$, 최승구 $^{6}$, 장인호$^{7}$, 양만길 $^{8}$ \\ ${ }^{1}$ 삼성서울병원 진단검사의학과, ${ }^{2}$ 을지대학교 임상병리학과, ${ }^{3}$ 연세대학교 보건과학대학 임상병리학과, ${ }^{4}$ 진주보건대학교 임상병리과, ${ }^{5}$ 대전대학교 \\ 임상병리학과, ${ }^{6}$ 신한대학교 임상병리학과, ${ }^{7}$ 상지대학교 임상병리학과, ${ }^{8}$ 서울대학교의생명연구원 연구실험부
}

\begin{abstract}
The Korean Society for Clinical Laboratory Science publishes the Korean Journal of Clinical Laboratory Science (KJCLS) as the official journal for the Korean Association of Medical Technologists. This year, 2017, marks the 50th anniversary of KJCLS. The original name was "the Korean Journal of Medical Technologists" (Volume 1, 1967 Volume 26, 1994), which was replaced with the "Korean Journal of the Clinical Laboratory Science" (Volume 27, 1995 Volume 35, 2003) and "the Korean Journal of Clinical Laboratory Science" (Volume 26, 2004 Present). The purpose of this study was to provide a framework for further development of KJCLS. In 1998, the National Research Foundation of Korea began the journal assessment service. The major domestic databases are $\mathrm{KCI}$, KOFST, and KAMJE; the major international databases are $\mathrm{SCI}$ Index; $\mathrm{SCl}$ Core, SCl-Extended), SCOPUS, MEDLINE, and PUBMED. KJCLS has been registered with $\mathrm{KCl}$ of the National Research Foundation of Korea since 2014. More than 1,300 articles have been published, which all have made tremendous contributions to the field. To index KJCLS in the journal databases, we measured the value to understand the vocational level and social position. KJCLS is faced with a great challenge; immense effort will be needed to accomplish the original goal of KJCLS to become an internationally recognized journal. Ultimately, the goal of the Korean Society for Clinical Laboratory Science and the Korean Association of Medical Technologists should be to register $\mathrm{KJCLS}$ in databases such as $\mathrm{KCl}$ and SCOPUS.
\end{abstract}

Key words: Clinical laboratory science, Medical technologist, Korea citation index

This is an Open Access article distributed under the terms of the Creative Commons Attribution Non-Commercial License (http://creativecommons.org/licenses/by-nc/4.0) which permits unrestricted non-commercial use, distribution, and reproduction in any medium, provided the original work is properly cited.

Copyright (c) 2017 The Korean Society for Clinical Laboratory Science. All rights reserved.
Corresponding author: Man-Gil Yang Department of Research and Experiment, Seoul National University Hospital Biomedical Research Institute, 101 Daehak-ro, Jongno-gu, Seoul 03080, Korea

Tel: 82-2-2072-1991

Fax: 82-2-762-5178

E-mail: mangil78@hanmail.net

Received: June 21, 2017

Revised 1 1 st: June 26, 2017

Revised $2^{\text {nd }}$ : June 26,2017

Accepted: June 26, 2017 


\section{서 론}

대한임상병리사협회(이하 본 회) 공식 학술지는 1967년 창 간된 “대한임상병리사회지, 1995년 대한임상병리검사과학회 지, 2004년 대한임상검사학회지, 2014년 개명한 대한임상검 사과학회”로 현재까지 발간하고 있다. 지난 본 회는 학술지와 관련하여 세 가지 전략 부재가 있었다.

《첫 번째, 전략 부재》는 학술지의 개명 시기가 현저하게 늦 었다. 1967 1994년 발간된 대한 임상병리사회지는 문공부에 정기간행행물로 등록되어 있지 않아 교직에 종사하고 있는 회 원들 이 투고를 기피하는 현상이 있었다. 1992년 문공부에 신청 하여 등록번호 아-187호로 인가되었으나, 학회지 명칭이 “○ $\bigcirc$ 학회지” 가 아니고 “ $\bigcirc \bigcirc$ 사 회지”로 되어서 대한임상병리사 회지가 학술지가 아닌 기관지로 분류되는 문제점이 생겼다[1]. 본 회가 당시 1979년 대한치과기공학회지, 1983년 대한방사선 기술학회지, 1996년 대한핵의학기술학회지를 참고하여 일찌 감치 "대한임상검사기술학회지, 대한임상병리기술학회지 또 는 대한임상병리사협회 학술지” 등으로 개명했다면 정식 학술 지로 인정받았을 것이다.

《두 번째, 전략 부재》는 전문학회의 설립 시기가 현저하게 늦었다. 대한방사선사협회는 1976년 한국방사선기술연구회, 대한방사선기술 학회를 거쳐 지금의 대한방사선과학회, 대한 물리치료사협회는 1976년 대한물리치료사학회를 거쳐 대한물 리치료과학회, 대한작업치료사협회는 1993년 대한작업치료 학회, 대한치과기공사협회는 1979년 대한치과기공학회, 대한 치과위생사협회는 1994년 대한치과위생학회, 대한의무기록 사협회는 1995년 대한보건정보관리학회, 대한안경사협회는 1999년 대한시과학회가 설립되었다. 본 회의 경우, 임상병리과 교수들이 모여 1978년 가칭 “대한임상병리기술학회” (회장 양 용석 신흥보건전문학교 교수, 총무 이창규 고려대학교병설 의 학기술초급대학 교수)가 설립하였으나, 오히려 본 회에서 여러 사유를 들어 학회 관계자에게 학회를 해체하도록 인적, 법적 경 고하였으며 그 해 학회는 우여 곡절 끝에 해산하게 되었다[1]. 이 후 임상병리학과 교수를 중심으로 한 의생명과학자들이 새로이 모여서 1995년 대한 의생명과학회(발기인 양용석 연세대학교 교수, 김종배 연세대학교 교수, 김용호 인제대학교 교수, 문희주 서울보건대학 교수, 신영오 국립보건원 박사)를 설립 하였다 [2]. 본 회는 국내외 전문학회 운용, 학술지 등재, 학문 동향에 따 른 시행착오 끝에 뒤늦게나마 2009년 “대한임상검사학회”를 설립하였다.

《세 번째, 전략 부재》는 학술지의 등재 시기가 현저하게 늦
었다. 교육부와 한국연구재단은 1998년에 학술지 등재사업을 처음 시행하였다. 2016년 한국연구재단 학국학술지인용색인 (Korean Citation Index, KCI)에 의하면 의료기사, 의무기록 사, 안경사, 간호사, 영양사 중 에서 $\mathrm{KCI}$ 급 학술지를 많이 발행 하는 단체로는 간호사 21 개, 물리치료사 7 개, 영양사 6개 순이 었다(Table 1). 학술지 등재제도는 2011년까지 시행하다가 2012 2013년 학술지 평가 유예 후 폐지로 가닥을 잡았다가 교 수, 연구자들의 반발로 제도 개선을 통해 2014년 학술지 평가를 재시행하게 되었다. 본 회는 1998년부터 2011년까지 학술지 평가를 신청한 적이 없다. 학술지 평가 신청여부는 외부적 요인 보다 내부적 요인으로 인해 기회를 놓친 것으로 생각된다. 2016 년 한국연구재단에 등록된 $\mathrm{KCI}$ 등재학술지는 1,989 종, $\mathrm{KCI}$ 등 재후보 학술지는 296종이며 미등재학술지는 3,012종이 있다 [3]. 본 회의 학술지가 오랜 기간 동안 미등재학술지였던 사실, 타의료기사 학술단체 중 가장 늦게 등재(후보)학술지가 되었다 는 사실이 선후배들에게 매우 부끄러울 따름이다.

2017년은 대한임상병리사협회 공식 학술지가 1967년 창간 된 이래 50 주년을 맞는 해이면서 대한임상검사과학회지가 2014년 12월 KCI 등재후보학술지에 이어 2017년 8월 KCI 등 재학술지로 선정된 뜻 깊은 해이기도 하다. 대한임상검사과학 회지는 보건과학대학 임상병리학과 교수, 실무 임상병리사 등 이 작성한 연구논문을 게재하여 회원들의 구독, 활용, 평판, 선 호도에서 명실상부한 임상병리사의 대표 학술지라고 자부할 수 있다. 그동안 대한임상검사과학회지는 오랜 역사와 전통을 이 어갈 뿐만 아니라 우수학술지로 발돋움하기 위해 다양한 노력 을 기울인 점과 향후 발전방안을 모색하고자 한다.

\section{본 론}

\section{1. 임상검사, 임상병리}

\section{1) 임상병리사 명칭의 유래}

우리나라 임상병리사 단체의 역사는 1962년 10월 가칭 "대 한임상검사기술협회”, 1963년 10월 가칭 “대한임상병리기사 회(大韓臨床病理技師會)”를 거쳐 1965년 12월 보건사회부로 부터 허가를 받은 "사단법인 대한임상병리사협회(Korean Association of Medical Technologists)"이다[1]. 당시 본 회는 일본 후생성에서 면허 인정하는 일본임상위생검사기사회의 “임상검사기사(臨床檢查技師)” 명칭과 일본임상병리의학회 및 일본임상병리동학원에서 개인 자격 인정하는 "임상병리기 술사(臨床病理技術士)” 명칭을 두고 검토하다가 지금의 “임상 병리사(臨床病理士)”로 작명하였다[4]. 그러나 일본의 경우, 
Table 1. Organizations of medical service technologists, medical record administrator, optician, nurse, and dietitian in National Research Foundation of Korea in 2016

\begin{tabular}{|c|c|}
\hline Organization & $\mathrm{KCl}$ Journal publisher \\
\hline KAMT and council of professors (2) & $\begin{array}{l}\text { - Korean Society for Clinical Laboratory Science (대한임상검사과학회) } \\
\text { - Korean Society for Biomedical Laboratory Sciences (대한의생명과학회) }\end{array}$ \\
\hline KRTA and council of professors (2) & $\begin{array}{l}\text { - Korean Society of Radiological Science (대한방사선과학회) } \\
\text { - Korean Society of Radiology (한국방사선학회) }\end{array}$ \\
\hline KPTA and council of professors (7) & $\begin{array}{l}\text { - Korean Society of Physical Therapy (대한물리치료학회) } \\
\text { - Korean Research Society of Physical Therapy (한국전문물리치료학회) } \\
\text { - Korean Society of Sports Physical Therapy (대한스모츠물리치료학회) } \\
\text { - Korean Academy of Physical Therapy Rehabilitation Science (물리치료재활과학회) } \\
\text { - Korean Society of Medicine and Therapy Science (대한치료과학회) } \\
\text { - Korean Society of Physical Medicine (대한물리의학회) } \\
\text { - International Academy of Physical Therapy Research (국제물리치료학회) }\end{array}$ \\
\hline KOTA and council of professors (3) & $\begin{array}{l}\text { - Korean Society of Occupational Therapy (대한작업치료학회) } \\
\text { - Korean Society of Community Based Occupational Therapy (대한지역사회작업치료학회) } \\
\text { - Korean Society of Sensory Integration (대한감각통합치료학회) }\end{array}$ \\
\hline KDTA and council of professors (1) & - Korean Academy of Dental Technology (대한치과기공학회) \\
\hline KDHA and council of professors (2) & $\begin{array}{l}\text { - Korean Society of Dental Hygiene (한국치과위생학회) } \\
\text { - Korean Society of Dental Hygiene Science (한국치과위생과학회) }\end{array}$ \\
\hline KMRA and council of professors (1) & - Korean Academy of Health Policy and Management (한국보건행정학회) \\
\hline KOA and council of professors (2) & $\begin{array}{l}\text { - Korean Society of Vision Science (대한시과학회) } \\
\text { - Korean Ophthalmic Optics Society (한국안광학회) }\end{array}$ \\
\hline KNA and council of professors (21) & $\begin{array}{l}\text { - Korean Society of Nursing science (한국간호과학회) } \\
\text { - Korean Academy of Nursing Administration (한국간호행정학회) } \\
\text { - Korean Academy of Fundamental of Nursing (한국기본간호학회) } \\
\text { - Korean Society of Biological Nursing Science (한국기초간호학회) } \\
\text { - Korean Society of Woman Health Nursing (한국여성건강간호학회) } \\
\text { - Korean Society of Adult Nursing (한국성인간호학회) } \\
\text { - Korean Academy of Child Nursing (한국아동간호학회) } \\
\text { - Korean Academy of Psychiatric and Mental Health Nursing (한국정신간호학회) } \\
\text { - Korean Academy of Community Health Nursing (한국지역사회간호학회) } \\
\text { - Korean Academic Society of Nursing Education (한국간호교육학회) } \\
\text { - Korean Academic Society of Home Care Nursing (한국가정간호학회) } \\
\text { - Korean Gerontological Nursing Society (한국노인간호학회) } \\
\text { - Korean Society of Public Health Nursing (한국보건간호학회) } \\
\text { - Korean Academic Society of Rehabilitation Nursing (한국재활간호학회) } \\
\text { - Korean Society of Critical Care Nursing (한국중환자간호학회) } \\
\text { - Korean Academic Society of Occupational Health Nursing (한국직업건강간호학회) } \\
\text { - Korean Oncology Nursing Society (대한종양간호학회) } \\
\text { - Korean Society of Muscle and Joint Health (대한근관절건강학회) } \\
\text { - Hospital Nurses Association (병원간호사회) } \\
\text { - Kyung Hee University East-West Nursing Research Institute (경희대학교 동서간호학연구소) } \\
\text { - Pusan National University Research Institute of Nursing Science (부산대학교 간호과학연구소) }\end{array}$ \\
\hline KDA and council of professors (6) & $\begin{array}{l}\text { - Korean Dietetic Association (대한영양사협회) } \\
\text { - Korean Society of Community Nutrition (대한지역사회영양학회) } \\
\text { - Korean Nutrition Society (한국영양학회) } \\
\text { - Korean Society of Clinical Nutrition (한국임상영양학회) } \\
\text { - Korean Society of Food \& Nutrition (한국식품영양학회) } \\
\text { - Korean Society of Food Science \& Nutrition (한국식품영양과학회) }\end{array}$ \\
\hline
\end{tabular}

Abbreviations: KCI, Korean Citation Index; KAMT, Korean Association of Medical Technologists; KRTA, Korean Radiological Technologists Association; KPTA, Korean Physical Therapy Association; KOTA, Korean Association of Occupational Therapists; KDTA, Korean Dental Technologists Association; KDHA, Korean Dental Hygienists Association; KOA, Korean Optometric Association; KMRA, Korean Medical Record Association; KNA, Korean Nurses Association; KDA, Korean Dietetic Association.

2003년 일본임상병리의학회 및 일본임상검사동학원이 일본임 상검사의학회 및 일본임상검사동학원으로 개명되면서 자연스 럽게 임상병리기술사 명칭을 “임상검사사(臨床檢査士)”로 변
경하였다[5]. 임상병리사-medical technologist) 명칭은 의료 기사직군 중에서 유일하게 국영문이 불일치하여 번역, 검색, 인 용, 홍보 등에서 오류를 초래하고 있어 문제이다. 본 회 회원조 
Table 2. Comparative review of medical technologists' name

\begin{tabular}{ll}
\hline \multicolumn{1}{c}{ English name } & \multicolumn{1}{c}{ Translatable Korean name } \\
\hline Medical technologist & - 임상병리사(현행; 국영문 불일치) \\
Medical laboratory technologist & - 의학검사사('검사사' 발음 불편) \\
& - 의학검험사(임상병리학과에서 의학검험학과로 변경 시 '학'자 중복으로 표현 어색) \\
Biomedical laboratory technologist & - 의생명검사사('검사사' 발음 불편) \\
& - 의생명검험사(임상병리학과에서 의생명검험학과로 변경 용이) \\
Clinical laboratory technologist & - 임상검사사('검사사' 발음 불편) \\
& - 임상검험사(국영문 일치; 임상병리학과에서 임상검험학과로 변경 용이) \\
Laboratory biomedicine technologist & - 검리사(檢理士; '변리사, 감리사, 요리사, 조리사' 사례; 3글자; 신조어) \\
Clinical pathologic technologist & - 임상병리사(국영문 일치; 국제적 명칭 아님) \\
Pathological technologist & - 병리사(국영문 일치; 임상병리사의 호칭; 국제적 명칭 아님) \\
\hline
\end{tabular}

차 임상병리사 영문 medical technologist에 대하여 제대로 인 식을 하지 못하고 있는 실정이며, 각종 문헌에서 임상병리사를 clinical pathologic technologist, clinical pathology technician로 직역하여 표현하기도 한다. 임상병리사 직급이 일원 화되어 있는 우리나라의 경우, 다른 의료기사직군처럼 정확한 번역과 표현의 일관성 확보를 위해서 국영문이 일치된 명칭을 검토해야 할 것으로 생각된다(Table 2).

\section{2) 임상병리사 명칭의 직급}

공식적으로 임상병리사 명칭의 효시는 1912년 영국의 “pathological and bacteriological laboratory assistant"이 다[6]. 임상병리사 직급이 일원화되어 있는 국가는 "technologist" 제도를 운용하고 있으며 $[1,7,8]$, 이원화되어 있는 국 가의 경우 정도관리, 검체분석, 결과 보고, 복잡난이도검사 업무 를 수행하는 "technologist (scientist)"와 채혈, 접수, 전처리, 단순검사 업무를 수행하는 "technician (assistant)" 제도를 운 용하고 있다[9-15].

\section{3) 임상병리사 학회의 명칭}

학회나 학술지 명칭이 technology에서 science로 개명된 시 발점은 영국 임상병리사 학술단체로 1943년 IMLT (Institute of Medical Laboratory Technology)는 1974년 IMLS (Institute of Medical Laboratory Sciences)를 거쳐 1994년 지금의 IBMS (Institute of Biomedical Science)가 있다[6]. 미국 임상병리사 학술단체의 경우 ASMT (American Society for Medical Technology)는 1993년 ASCLS (American Society for Clinical Laboratory Science)로 개명하였고[11], 이러한환경 변화로 국제임상병리사연맹도 IAMLT (International Association of Medical Laboratory Technologists)에서 2000년 IFBLS (International of Biomedical Laboratory Science)로 개명하게 되었다[16].

\section{4) 임상병리사 학문의 명칭}

본 회의 임상병리사 학문은 1962년 대한임상검사기술협회 회칙의 “임상검사기술학”을 거쳐 1965년 대한임상병리사협회 정관의 “임상병리기술학", 이후 1996년 정관 개정을 통해 “임 상병리검사학”을 사용하고 있다. 국제적인 영문 표기로는 "medical technology, clinical laboratory technology, medical laboratory technology, clinical laboratory science, medical laboratory science, medical laboratory science and biotechnology, biomedical laboratory science"를 사용하고 있다. 특히 medical technology를 임상 병리기술학으로 학문 정의하기엔 무리가 있다. 우리와 관련된 medical technology는 협의 개념에서 “의학검사기술학” 으로 소개되기도 하지만 광의 개념으로는 의학검사기술, 의료기기, 의료정보기술, 생명공학 및 건강관리서비스를 포함한 "의료기 술”로 정의하고 있다. 이러한 technology의 융복합화 명칭은 보건의료기술, 생명공학기술, 정보기술, 환경공학기술, 우주항 공기술, 나노기술, 문화콘덴츠기술 등에서 찾아볼 수 있다.

\section{2. 학술지 체제 정비}

\section{1) 학술지명, 학술지 표지의 변천}

학술지 표지는 학술지명에 따라 변경되었다. 1967년 창간된 제1권 대한임상병리사회지(Korean Journal of Medical Technologists), 1995년 제27권 대한임상병리검사과학회지 (Korean Journal of the Clinical Laboratory Science), 2004 년 제36권 대한임상검사학회지(Korean Journal of Clinical Laboratory Science)를 거쳐 2014년 제46권 대한임상검사과 학회지(Korean Journal of Clinical Laboratory Science, KJCLS)의 표지가 현재까지 사용되고 있다(Figure 1). 특히 대한 임상검사과학회 심벌마크는 구본경 편집 위원과 성호중 편집위 원이 공동으로 디자인하였으며(Figure 2), 제46권 표지 및 제 48 권 세부학문분야의 심벌마크는 구본경 편집위원이 직접 디자인 


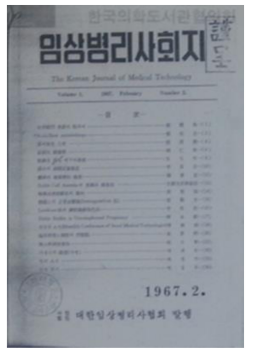

1967 Vol. 1

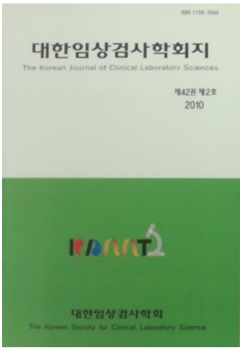

2010 Vol. 42

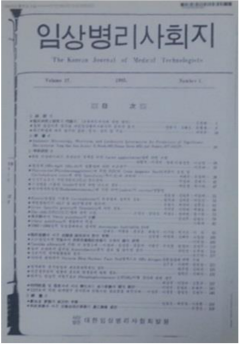

1985 Vol. 17

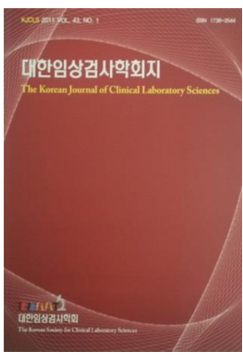

2011 Vol. 43

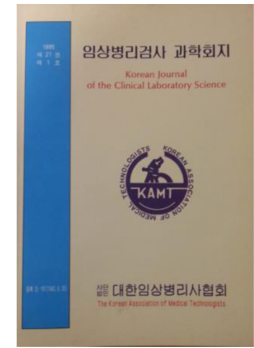

1995 Vol. 27

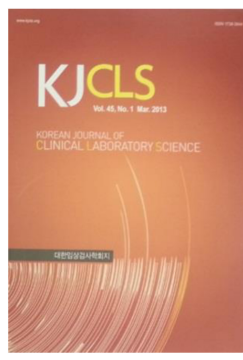

2013 Vol. 45

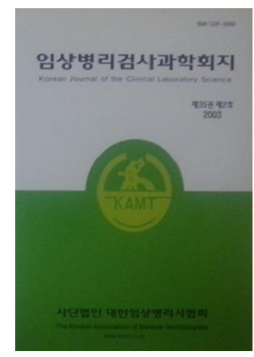

2003 Vol. 35

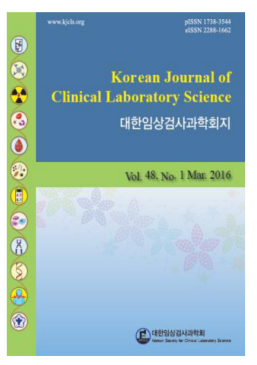

2016 Vol. 48
Figure 1. Changes of design of "Korean Journal of Medical Technologists" and "Korean Journal of Clinical Laboratory Science".

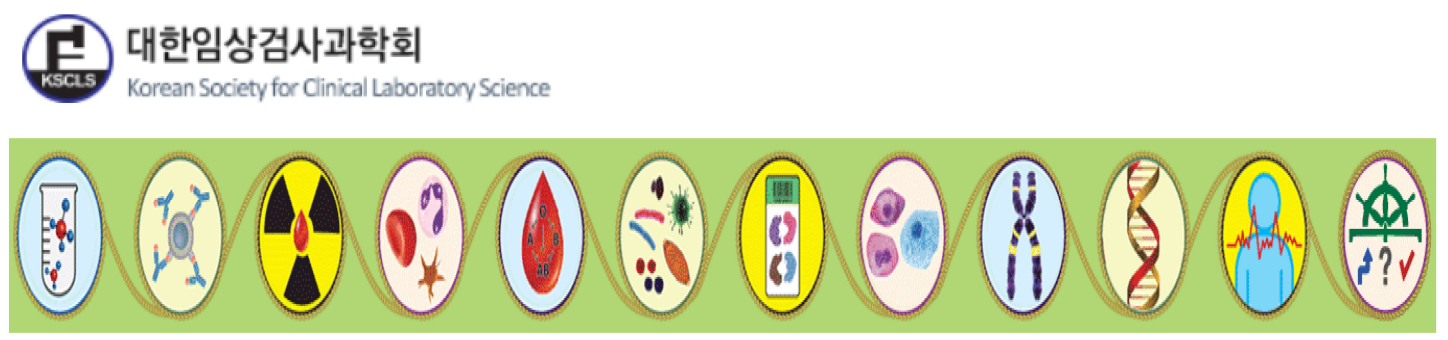

Figure 2. Symbols of "Korean Society for Clinical Laboratory Science" and "specialty areas". Biochemistry, immunology, in vitro nuclear medicine, hematology, transfusionology, microbiology, parasitology, histology, cytology, cytogenetics, molecular genetics, electrophysiology, and laboratory information.

하여 학술지의 변신을 시도하였다(Figure 2).

\section{2) 정기간행물번호의 변천}

정기간행물번호는 제27권에 등록번호 아-187호, 제31권에 국제표준연속간행물번호 ISSN 1229-2850, 제36권에 국제표 준연속간행물번호 pISSN 1738-3544, 제45권에 국제표준연 속간행물번호 eISSN 2288-1662를 표기하고 있다.

\section{3) 발행 간기의 변천}

발간호인 제 1 권을 제외하고 제2권부터 제34권까지는 연 1 회 발간되었으며, 제 35 권부터는 연 2 회 발간, 제 37 권부터는 연 3 회 발간, 제 41 권부터는 연 4회 발간하고 있다.

\section{4) 논문투고규정의 변천}

논문투고규정은 제1권에 11 13개 조문, 제25권에 15 17 개 조문, 제 46 권에 18 20개 조문을 사용하고 있다. 특히 제 47 권은 완전 개정된 논문투고규정으로 본문 내 문헌 인용과 참고 문헌 작성 표기를 Vancouver style (NLM [National Library of Medicine] style; AMA [American Medical Association] style)을 준용하여 작성하고 있다. 투고자, 심사자, 편집자의 원 고 오류나 편집 오류를 줄이는 효과가 있었다.

\section{5) 영문초록의 변천}

영문초록은 초창기에는 제대로 갖추지 못한 것들이 더러 있 었으나, 수차에 걸친 투고규정의 수정보완과 편집위원들의 꾸 준한 노력으로 정비되었다고 볼수 있다. 영문초록은 제 18 권에 
이르러서야 전 논문에 첨부되기 시작했다.

\section{6) 연구윤리규정의 첨부}

연구윤리규정은 제 42 권부터 학술지 후면부에 논문투고규정 과 함께 첨부되었다. 투고자가 준수해야 할 연구출판윤리와 연 구부정행위 등에 대한 기준 및 벌칙사항이 기술되었다.

\section{7) 교신저자의 표시}

교신저자는 제 35 권부터 제 1 저자, 공동저자 외에 학술지 편 집자 또는 다른 연구자들과 연락을 취할 수 있도록 교신저자를 지정하도록 하였다. 교신저자를 지정한 이유는 논문과 관련하 여 질문이 있거나 문제점이 발견되었을 때 연락을 취하여 조치 하도록 하기 위한 것이다.

\section{8) 학술지 약어의 표시}

학술지 약어는 제39권부터 페이지 상단에 "Korean J Clin Lab Sci”를 표시하였다. 모든 참고문헌이 영문으로 작성하기 시 작한 제45권부터는 본 회 학술지명도 "Korean J Clin Lab Sci" 로 표기하였다. 참고문헌에서 학술지 표기가 중요한 이유는 약 어를 기준으로 자동적으로 영향력지수를 산정하기 때문이다.

\section{9) 과학회지에 학술대회 초록 게재}

과학회지에 심포지엄이나 초록이 게재된 것은 제30권 1 2 호, 제31권 1호, 제32권 1 2호, 제33권 1호, 제34권 1호로 종 합학술대회 초록집이 포함된 적이 있었다. 일반적으로 학술대 회 프로시딩이나 학술대회 초록은 전문가 심사과정을 받지 않 기 때문에 정식 논문으로 인정하지 않는다. 또한 교육부에서 권 고하는 연구자실적지침의 경우, 학술지 논문을 기재하는 "논문 실적”과 프로시딩, 초록을 기재하는 “학술활동실적” 으로 구분 하여 입력하도록 되어 있다.

\section{0) 분과학회지의 논문 게재}

현재 10 개 분과학회지는 초록, 심포지엄 형식을 갖춘 학술대 회 초록집이다. 일부 시기에 학술대회 초록과 논문을 함께 게재 하여 “OOO 학회지”로 변화를 시도하였으나, 논문 게재의 어려 움으로 “OOO 학술대회 초록집” 으로 다시 회귀하게 되었다. 당 시 분과학회지에 게재된 논문의 경우, 양질의 논문이 유지관리 도 안된 채 사장(死藏)되었으며 다수의 논문에서 투고규정에 맞 지 않는 내용, 분량이 적은 내용 등이 발견되었다. 이러한 시행 착오는 회원수준, 심사과정, 원고편집, 정책추진에 대한 집행부 의 의지와 경험이 부족했기 때문이다. 오히려 집행부는 현실을
고려하여 학술대회 초록과 학술지 논문의 전단계인 학술대회 프로시딩으로 준비했다면 지속적인 발행이 가능했었을 것이라 생각된다. 다른 사례로 대한방사선협회 핵의학기술연구학회와 대한임상병리사협회 핵의학검사학회가 통합하여 설립한 대한 핵의학기술학회에서 찾아 볼 수 있다. 대한핵의학기술학회에 서 발행하는 "대한핵의학기술학회지(1996년 제1권 1999년 제4권)", “핵의학기술(2000년 제5권 현재)”의 경우, 정식 학 술지 형식은 아니지만 학술대회 초록과 논문을 함께 게재한 것 이 특징이다.

\section{3. 학술지 등재 추진}

\section{1) 종합학술대회의 주관}

2004년 10월 본 회(협회장 안용호, 편집위원장 김태운)는 종 합학술대회의 경우 운영 주최를 중앙회 또는 시도회, 학술 주관 은 가칭 대한임상검사학회에서 분담하기로 정했다. 그래서 종 합학술대회 초록집에 주관 표기가 처음 등장한 것이다. 대한임 상검사학회는 2006년 9월 서울에서 개최하는 국제임상병리사 연맹 세계학술대회(27th world congress of biomedical laboratory science, IFBLS)를 협회, 편집위원회, 교수협의회 가 협업하여 성공적으로 진행하고자 설립된 학회이지만 회칙 등은 제정되지 않았다. 참고로 한국연구재단이나 한국과학기 술단체총연합회에서는 일정 수준의 학회에 대해서 학술대회 운 영 경비, 학술지 발간 경비를 지원하고 있는데 두 기관이 공동 개 최할 경우, 주관하는 기관이 경비를 신청할 수 있게끔 되어 있다.

\section{2) 과학회, 분과학회, 전문임상병리사 명칭의 개명}

2009년 9월 본 회(협회장 안용호, 편집위원장 김신무)는 학 술지 등재, 학술지 발간, 종합학술대회 주관, 연구 활동을 목적 으로 대한임상검사학회를 설립하였다. 이후 2014년 4월 본 회 (협회장 양만길, 편집위원장 최승구)는 대한임상검사학회 명칭 을 대한임상검사과학회로 개명하였다. 2016년 2월 개정된 대 한임상검사과학회 회칙의 특이점은 기존 정회원, 명예회원 외 에 특별회원을 추가하였다. 특별회원 자격은 임상병리사 면허 증을 소지하지 않고 대학에서 임상 병리학과 소속으로 있으면 서 전공 관련 교과목을 강의하는 자로 규정하였다. 본 회는 임상 병리사 학문 명칭을 1962년 임상검사기술학, 1965년 임상병리 기술학, 1996년 임상병리검사학으로 표현하여 정관에 명시하 고 있으며, 한국연구재단 학술연구분야 등재(학문 등재)와 관련 하여 2016년 6월 “임상병리검사학 학문 정립을 위한 연구과 제”를 공모하였다. 2015년 12월 본 회는 분과검사학회 및 전문 임상병리사의 명칭을 국내외적 증빙자료를 토대로 (1) 국영문 
의 일치성, (2)의사 학회와의 차별성, (3) 임상병리사 학회의 정 체성을 나타내는 용어로 변경하 였다(Table 3). 검사학회 명칭 의 경우, $\mathrm{A}$ 안은 임상 $\bigcirc 0 \bigcirc$ 검사학회(society for clinical laboratory $\bigcirc 00$ ) 또는 $\bigcirc 0 \bigcirc$ 검사학회(society of $\bigcirc 00$ technology), B안은 $\bigcirc \bigcirc \bigcirc$ 검사학회(experiment society of O००; analysis society of $\bigcirc 00$; laboratory society of $\bigcirc \bigcirc$ ○; research society of $\bigcirc 00$ ), C안은 $\bigcirc 0 \bigcirc$ 검사학회 (society of $\bigcirc 00$ laboratory)이었다. 또한 전문임상병리사 영 문 명칭으로 $\mathrm{A}$ 안은 specialist in $\bigcirc 0 \bigcirc, \mathrm{B}$ 안은 certificated of specialized medical technologist, $\bigcirc 00, \mathrm{C}$ 안은 certified $\bigcirc$ $\bigcirc$ technologist 이었다.

3) 중앙회, 분과학회, 시도회, 전문임상병리사위원회의 학 술지 게재논문 지원사업

1993년 3월 본 회는 학술상을 제정하여 대한임상검사과학
회지 게재논문 중 우수논문을 엄선하여 종합학술대회에서 시상 하고 있으며, 분과학회는 해당 분야의 대한임상검사과학회지 게재논문 중에서 심의하여 분과학술대회 개최 시 학술상을 시 상하고 있다(Table 4). 2014년 6월 시도회는 회원들의 활발한 연구 활동을 장려하는 차원에서 대한임상검사과학회지 게재논 문에 대하여 편당 논문지원금을 지원하고 있다. 또한 2009년 9 월 전문임상병리사제도 운영위원회는 해당분야의 자격 유지를 위한 보수교육 평점(5년에 최소 50 평점) 중에서 대한임상검사 과학회지 게재논문의 주저자인 제 1저자에게 10 평점, 교신저 자에게 5 평점을 배점해 주고 있다.

\section{4) 교수협의회의 협조}

2014년 7월 한국임상병리학과교수협의회는 회원들에게 대 한임상검사과학회지가 우수학술지로 거듭날 수 있도록 영향력 지수(피인용지수)의 상승을 위해서 회원들이 발표하는 $\mathrm{KCI}$ 등

Table 3. Name change of academic society and specialized medical technologist in 2016

\begin{tabular}{|c|c|}
\hline Before & After \\
\hline $\begin{array}{l}\text { Korean Society of Technical Hematology } \\
\text { (대한혈액검사학회) }\end{array}$ & $\begin{array}{l}\text { Korean Society for Clinical Laboratory Hematology } \\
\text { (대한임상혈액검사학회) }\end{array}$ \\
\hline $\begin{array}{l}\text { Korean Society of Blood Transfusion Laboratory Science } \\
\text { (대한수혈검사학회) }\end{array}$ & $\begin{array}{l}\text { Korean Society for Clinical Laboratory Blood Bank* } \\
\text { (대한임상수혈검사학회) }\end{array}$ \\
\hline $\begin{array}{l}\text { Korean Society of Clinical Chemical Science } \\
\text { (대한임상화학검사학회) }\end{array}$ & $\begin{array}{l}\text { Korean Society for Clinical Laboratory Chemistry } \\
\text { (대한임상화학검사학회) }\end{array}$ \\
\hline $\begin{array}{l}\text { Korean Society of Immunological Laboratory Science } \\
\text { (대한면역검사학회) }\end{array}$ & $\begin{array}{l}\text { Korean Society for Clinical Laboratory Immunology } \\
\text { (대한임상면역검사학회) }\end{array}$ \\
\hline $\begin{array}{l}\text { Korean Society of Microbiological Laboratory Science } \\
\text { (대한미생물검사학회) }\end{array}$ & $\begin{array}{l}\text { Korean Society for Clinical Laboratory Microbiology } \\
\text { (대한임상미생물검사학회) }\end{array}$ \\
\hline $\begin{array}{l}\text { Korean Academy of Histology and Cytology } \\
\text { (대한조직세포검사학회) }\end{array}$ & $\begin{array}{l}\text { Korean Experiment Society of Histology and Cytology } \\
\text { (대한조직세포검사학회) }\end{array}$ \\
\hline $\begin{array}{l}\text { Korean Analysis Association of Nuclear Medicine Technology } \\
\text { (대한핵의학검사학회) }\end{array}$ & $\begin{array}{l}\text { Korean Society of Nuclear Medicine Technology } \\
\text { (대한핵의학기술학회) (integration of KAMT and KRTA in 1998) }\end{array}$ \\
\hline $\begin{array}{l}\text { Korean Society of Public Health Laboratory } \\
\text { (대한공중보건검사학회) }\end{array}$ & $\begin{array}{l}\text { Korean Society of Public Health Laboratory } \\
\text { (대한공중보건검사학회) }\end{array}$ \\
\hline $\begin{array}{l}\text { Korean Society of Physiological Science } \\
\text { (대한생리학검사학회) }\end{array}$ & $\begin{array}{l}\text { Korean Society for Clinical Laboratory Physiology } \\
\text { (대한임상생리검사학회) }\end{array}$ \\
\hline $\begin{array}{l}\text { Korean Society of Clinical Laboratory Informations Association } \\
\text { (대한임상검사정보학회) }\end{array}$ & $\begin{array}{l}\text { Korean Society for Clinical Laboratory Information } \\
\text { (대한임상검사정보학회) }\end{array}$ \\
\hline $\begin{array}{l}\text { Specialist in Technical Hematology } \\
\text { (혈액학검사 전문임상병리사) }\end{array}$ & $\begin{array}{l}\text { Specialist in Hematology } \\
\text { (혈액전문임상병리사) }\end{array}$ \\
\hline $\begin{array}{l}\text { Specialist in Blood Bank } \\
\text { (수혈 전문임상병리사) }\end{array}$ & $\begin{array}{l}\text { Specialist in Blood Bank } \\
\text { (수혈전문임상병리사) }\end{array}$ \\
\hline $\begin{array}{l}\text { Specialist in Chemistry } \\
\text { (임상화학 전문임상병리사) }\end{array}$ & $\begin{array}{l}\text { Specialist in Chemistry } \\
\text { (화학전문임상병리사) }\end{array}$ \\
\hline $\begin{array}{l}\text { Immunological Laboratory Specialist } \\
\text { (면역 전문임상병리사) }\end{array}$ & $\begin{array}{l}\text { Specialist in Immunology } \\
\text { (면역전문임상병리사) }\end{array}$ \\
\hline $\begin{array}{l}\text { Microbiological Laboratory Specialist } \\
\text { (미생물 전문임상병리사) }\end{array}$ & $\begin{array}{l}\text { Specialist in Microbiology } \\
\text { (미생물전문임상병리사) }\end{array}$ \\
\hline $\begin{array}{l}\text { Professional Histotechnologist } \\
\text { (조직 전문임상병리사) }\end{array}$ & $\begin{array}{l}\text { Specialist in Histology } \\
\text { (조직전문임상병리사) }\end{array}$ \\
\hline $\begin{array}{l}\text { Nuclear Medicine Laboratory Specialist } \\
\text { (핵의학 전문임상병리사) }\end{array}$ & $\begin{array}{l}\text { Specialist in Nuclear Medicine } \\
\text { (핵의학전문임상병리사) }\end{array}$ \\
\hline
\end{tabular}

*Alternative name: Clinical Laboratory Transfusionology, Blood Bank Technology.

${ }^{\dagger}$ Alternative name: Clinical Laboratory Histocytology, Pathological Technology. 
재(후보)학술지에 대한임상검사과학회지를 인용해 줄 것을 요 청하였다.

\section{5) 학술지 홈페이지, 온라인 논문투고심사시스템의 구축}

2013년 5월 본 회는 전문학회의 주요 활동인 논문 투고 및 심 사 업무를 자동화, 논문 및 심사 관련 자료의 유실 방지, 논문 자 료의 보관 유지, 학술지 평가자료 작성 등에서 용이하도록 대한 임상검사과학회지(http://www.kjcls.org/)와 온라인 논문투 고심사시스템(http://www.kjcls.org/submission/Login.html) 을 구축하였다.
6) 학회 홈페이지, 종합학술대회 온라인 초록투고시스템, $\mathrm{DOI}$, JATS XML의 구축

2014년 3월 본 회는 대한임상검사과학회(http://www. $\mathrm{kscls}$.or.kr/)와 종합학술대회 온라인 초록투고시스템(http:// www.kscls.or.kr/abstract/)을 구축하였다. 제46권은 CrossRef 사로부터 DOI (digital object identifier)를 발급 받아 게재논문 의 참고문헌에 고유한 DOI 번호를 부여하였다. 제 45 권부터 제 47 권은 게재논문에 있는 초록, 참고문헌, 본문에서 대해서 순차 적으로 JATS XML (journal article tag suite extensible markup language)로 변환하여 논문 검색 창에서 보여 주고 있다.

Table 4. Current status of academic award in 2016

\begin{tabular}{|c|c|}
\hline Organization & Academic award \\
\hline $\begin{array}{l}\text { Korean Association of Medical Technologists } \\
\text { Korean Society for Clinical Laboratory Science }\end{array}$ & Yes (300만 원) \\
\hline Seoul Medical Technologists Association* & Yes (30만 원) \\
\hline Busan Medical Technologists Association & None \\
\hline Daegu Medical Technologists Association & None \\
\hline Incheon Medical Technologists Association & None \\
\hline Gwangju Medical Technologists Association & None \\
\hline Daejeon Medical Technologists Association & None \\
\hline Ulsan Medical Technologists Association & None \\
\hline Gyeonggi-do Medical Technologists Association & Yes (20만 원) \\
\hline Gangwon-do Medical Technologists Association & None \\
\hline Chungcheongbuk-do Medical Technologists Association & None \\
\hline Chungcheongnam-do Medical Technologists Association & None \\
\hline Jeollabuk-do Medical Technologists Association & None \\
\hline Jeollanam-do Medical Technologists Association & Yes (30만 원) \\
\hline Gyeonsangbuk-do Medical Technologists Association & None \\
\hline Gyeongsangnam-do Medical Technologists Association & None \\
\hline Jeju-do Medical Technologists Association & None \\
\hline Korean Society for Clinical Laboratory Hematology ${ }^{\dagger}$ & None \\
\hline Korean Society for Clinical Laboratory Blood Bank & None \\
\hline Korean Society for Clinical Laboratory Chemistry & Yes (30만 원) \\
\hline Korean Society for Clinical Laboratory Immunology & None \\
\hline Korean Society for Clinical Laboratory Microbiology & Yes (50만 원) \\
\hline Korean Experiment Society of Histology and Cytology & Yes (100만 원) \\
\hline Korean Society of Nuclear Medicine Technology ${ }^{\ddagger}$ & Yes (100만 원) \\
\hline Korean Society of Public Health Laboratory & None \\
\hline Korean Society for Clinical Laboratory Physiology & None \\
\hline Korean Society for Clinical Laboratory Information & None \\
\hline Specialist in Hematology ${ }^{\S}$, SH(KAMT) & None \\
\hline Specialist in Blood Bank, SBB(KAMT) & None \\
\hline Specialist in Chemistry, SC(KAMT) & None \\
\hline Specialist in Immunology, SI(KAMT) & None \\
\hline Specialist in Microbiology, SM(KAMT) & None \\
\hline Specialist in Histology, SHT(KAMT) & None \\
\hline Specialist in Cytology, SCT(KAMT) & None \\
\hline Specialist in Nuclear Medicine, SNM(KAMT) & None \\
\hline
\end{tabular}

*16 Regional organization; ${ }^{\dagger} 10$ Academic organization; ${ }^{\dagger}$ Integration of KAMT and KRTA; ${ }^{\S} 8$ Certification committee. Abbreviations: KAMT, Korean Association of Medical Technologists. 


\section{7) 투고논문의 질 향상}

2015년 편집위원회는 영문초록의 검독, 감수를 전문가, 원 어민에게 의뢰하던 것을 2016년부터 영문논문 교정업체로 변 경하였으며 영문초록의 질적 수준을 높이기 위해서 영문 단어 수 범위 제시, 비정형 초록이지만 배경, 방법, 결과, 결론의 내용 을 포함하도록 논문투고규정을 개정하였다. 또한 주저자가 논 문 투고 시 연구윤리 교육이수증, 논문유사도검사 종합결과확 인서, 영문논문 교정확인서를 온라인 논문투고심사시스템에 탑재하도록 권고하고 있다.

\section{8) 과거 학술지, 학술대회 초록집의 보관}

2013년 5월 본 회는 온라인 논문투고심사시스템 구축 시 논 문 검색 창에 제35권부터 제 45 권 학술지를 $\mathrm{PDF}$ 로 변환하여 논 문 검색창에 보관하고 있었다. 이후 추가로 2014년 5월 학회 홈 페이지 구축 시 제1권부터 제 34 권 학술지를 본 회 서고, 국립중 앙도서관을 통해서 습득하여 창간호부터 모두 갖추게 되었다. 제1권부터 제 48 권 학술지까지 총 1,296 편의 논문은 회원, 일반 인이 공개적으로 열람 가능하며 무료로 자료를 인쇄할 수도 있 다. 또한 1990년도부터 춘추계 학술대회 초록집을 PDF 변환시 켜서 학술행사 자료창에 보관해 놓고 있다.

\section{9) 학술지의 납본, 기탁}

1983년 본 회는 국립중앙도서관에 처음 학술지를 납본하였 으나 지속적인 납본이 이루어지지 않아서 누락된 권호가 많았 다. 국립중앙도서관은 우리나라 도서관을 대표하는 공공기관 임에도 불구하고 사무국, 중앙회, 편집위원회간의 업무 분장이 제대로 이루어지지 않았던 것이다. 국회도서관은 2016년부터 학술지를 납본하고 있다. $\mathrm{KCI}$ 등재(후보)학술지의 경우 2016 년 12월 개정된 한국연구재단 학술지 등재제도 관리지침에는 양 기관에 학술지를 필수적으로 납본하도록 명시하고 있다. 학 술지 기탁은 한국연구재단 $\mathrm{KCI}$ 에 제 27 권, (주) 한국학술정정보 에 제 2 권, 한국과학기술단체총연합회 학술활동지원시스템에 제36권, 한국과학기술정보연구원 학술정보통합관리시스템에 제36권, 한국과학기술단체총연합회 Science Central에 제 47 권부터 제공하고 있다. 논문 공개는 연구 성과물의 장기적 보존, 공공 접근, 직업 이미지, 영향력지수 상승에 도움이 되기 때문이 다. 또한 종합학술대회 초록집 및 분과학술대회 초록집도 1990 년도부터 (주) 한국학술정보에 학술발표자료를 제공하고 있다.

10) 한국과학학술지편집인협의회의 회원가입 2016년 12월 본 회는 학술지의 편집, 발간, 등재에 관한 정보
를 교환하고 편집인 상호간의 교류 증진을 위해 한국과학학술 지편집인협의회(Korean Council of Science Editors, KCE)에 가입하였다.

\section{4. 학술지 평가기관}

국내 학술지 평가기관은 한국연구재단(National Research Foundation of Korea, NRF), 한국과학기술단체총연합회 (Korean Federation of Science and Technology Societies, $\mathrm{KOFST}$ ), 대한의학학술지편집인협의회(Korean Association of Medical Journal Editors, KAMJE)에서 이루어지고 있다.

\section{1) 한국연구재단의 학술지 평가제도}

한국연구재단의 학술지 평가제도는 국내학술지의 관리체계 확보를 통해 학술지의 질적 수준 향상 유도, 국내연구자들의 연 구경쟁력 제고 및 연구성과의 공유 활성화, 국내 우수 학술지의 국제경쟁력 강화에 기여하기 위한 목적으로 1998년 처음 시행 되었으며 인문, 사회, 예체능, 복합, 자연, 공학, 농수산해양, 의 약계열 전 분야를 대상으로 하고 있다[17]. 또한 인문, 사회, 예 체능, 복합 계열 학회에 대해서 학술대회 지원사업도 하고 있다. “KCI 등재(후보)학술지(KCI registered journal)” 선정기준은 신규평가에서 80점 이상을 득점해야 하면 미등재학술지에서 $\mathrm{KCI}$ 등재후보학술지(KCI candidated journal)로 선정되며, $\mathrm{KCI}$ 등재후보학술지가 계속평가에서 85점 이상을 득점하면 $\mathrm{KCI}$ 등재학술지(KCI accredited journal)로 선정된다. $\mathrm{KCI}$ 는 한국연구재단의 학술지평가를 통해 선정된 등재(후보)학술지 의 게재논문에 대한 서지정보와 인용지수 및 통계자료 등을 제 공하는 전문정보서비스이다[18]. 공신력 있는 $\mathrm{KCI}$ 등재(후보) 학술지는 교수, 연구자들의 업적평가에 반영되는 대단히 중요 한 지표이다.

\section{2) 한국과학기술단체총연합회의 학술지 평가제도}

한국과학기술단체총연합회의 학술지 평가제도는 과학학술 지 발행지원을 통한 학술단체의 학술활동 활성화를 도모하고 과학학술지의 기본적 국제 수준 양식과 형식(style and format) 을 제고하기 위한 목적으로 2012년 처음 시행되었으며 자연, 공 학, 농수산해양, 의약 계열 분야를 대상으로 하고 있다[19]. 또 한 자연, 공학, 농수산해양, 의약 계열 학회에 대해서 학술대회 지원사업도 하고 있으며 신청자격은 연 2회, 게재논문 20편 이 상의 학술지를 발간하는 법정 학술단체로 제한하고 있다. 대한 임상검사과학회는 사단법인 학회 또는 고유번호증 학회으로 설 립된 법정학술단체가 아니기 때문에 즉, 임의학술단체이기에 
Table 5. Journal assesment of KOFST in 2016

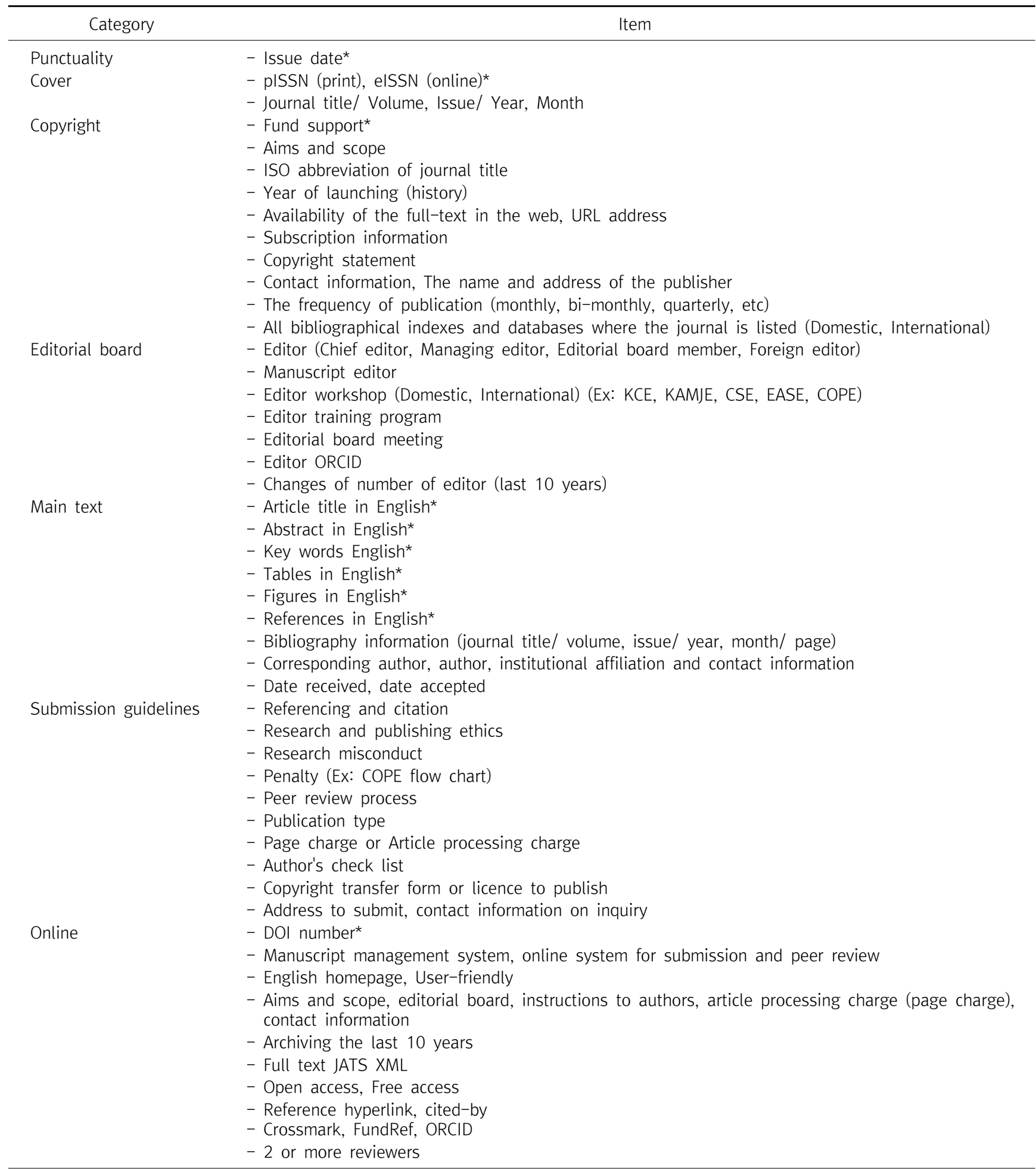

*Necessary.

Abbreviations: KOFST, Korean Federation of Science and Technology Societies; ISO, International Organization for Standardization; ORCID, open researcher and contributor ID; URL, uniform resource locator; ISSN, international standard serial number; KCE, Korean Council cf Science Editors; KAMJE, Korean Association of Medical Journal Editors; CSE, Council cf Science Editors; EASE, European Association of Science Editors; COPE, Committee on Publication Ethics; DOI, digital object identifier; JATS, journal article tag suite; XML, extensible markup language. 
한국과학기술단체총연합회에서 시행하는 학술지 및 학술대회 지원사업을 신청할 수 없다. 선정기준은 100 만점에 상위 $70 \%$ 이내에 들어오면 “과총등재학술지(KOFST registered journal)" 로 선정된다.

\section{3) 대한의학학술지편집인협의회의 학술지 평가제도}

대한의학학술지편집인협의회의 학술지 평가제도는 생의학 학술지의 수준을 향상시키기 위한 목적으로 1997년 시행되었 으며 의학, 치의학, 간호학, 보건학, 수의학, 영양학, 생명과학을 대상으로 하고 있다[20]. 선정기준은 종합평점 3.0 이상을 득점 하면 “의편협등재학술지(KoreaMed registered journal)"로 선정된다.

\section{5. 한국연구재단 학술지 평가기준}

한국연구재단의 학술지 평가기준은 필수 신청자격으로 (1) 발간의 규칙성 및 정시성(PASS/FAIL), (2) 논문당 심사위원수 (PASS/FAIL), (3) 연구윤리규정 제정(PASS/FAIL), 적용 및 공지 (PASS/FAIL), (4)논문명 및 저자명의 외국어화(PASS/FAIL), (5) 논문투고의 다양성(PASS/FAIL), (6) 한국학술지인용색인 등록 (PASS/FAIL)을 요구하고 있다. 체계평가는 (7)연간 학술지 발간 횟수(3점), 8)학술지 및 수록 논문의 온라인 접근성(7점), (9)주 제어 및 논문 초록의 외국어화(5점), (10) 게재논문의 투고, 심사, 게재확정일자 기재(4점), (11) 논문 게재율 (5점), (12) 편집위원장 의 안정성(2점) 항목으로 30점이다. 내용평가는 (13) 게재논문의 학술적 가치와 성과, $\mathrm{KCI}$ 인용지수 (10점), (14) 편집위원의 전문 성(15점), (15)논문집의 구성과 체제의 완전성 및 가독성 (10점), (16)투고논문 심사제도의 구체성 및 엄정성(15점), (17)논문 초록 의 질적 수준(5점), (18)연구윤리 강화활동의 구체성 및 엄정성(5 점) 항목으로 60점이다. 학문분야 특수평가는 (19) 저자 및 독자 의 현황과 확보 노력, (20)학술지의 질적 수준, (21)학회 활동성, (22) 사회적 기여도 항목으로 10 점이다. 대한임상검사과학회지는 한국연구재단의 학술지 평가기준에 따라 양질의 논문 발간, 논 문투고형식, 본문 내 인용방식, 참고문헌 작성방식, 연구출판윤 리, 연구부정행위 시 사후조치, 온라인 논문투고심사시스템, 논 문의 공개 열람, 논문의 무료 인쇄 등에서 다양한 변화를 주었 다. 대한임상검사과학회지는 2014년 12월 한국연구재단의 학 술지 신규평가에서 $\mathrm{KCI}$ 등재후보학술지로 선정되었다. 2015 년 유예기간을 거친 후 2016년 학술지 계속평가에서 KCI 등재 학술지로 승격되지 않고, $\mathrm{KCI}$ 등재후보학술지로 그대로 유지되 었다. 감점 내용은 논문투고규정에 어긋난 문구를 투고자, 심사 자, 편집자가 모두 놓쳤기 때문이다. 이를 타산지석의 계기로 삼
아 편집위원회는 게재논문에 편집 오류가 발생하지 않도록 세 밀한 교정, 교열을 수행하였고, 2017년 8월 학술지 평가에서 우 수한 점수를 받아서 $\mathrm{KCI}$ 등재학술지로 선정되었다.

\section{6. 한국과학기술단체총연합회의 학술지 평가기준}

대한임상검사과학회지는 한국과학기술단체총연합회 회원 학회는 아니지만 학술지 평가기준(Table 5)에 따라 서지유통의 국제성을 위해서 ISSN 번호, DOI 번호, ISO 학술지 약어를 등록 하였고, 논문인용의 확장성과 관련하여 제목, 저자, 소속, 초록, 중심단어, 표, 그림, 참고문헌을 영문으로 표기하고 있다. 또한 판권의 소유성을 위해서 학술지와 관련된 기본적인 정보를 기 재하고 있으며, 독자의 편의성과 관련하여 논문투고규정에 참 고문헌 작성양식뿐 아니라 연구출판윤리, 논문출판경비, 저자 점검표, 연구윤리서약서 및 저작권인계동의서 등을 기재하는 등 지속적인 변화를 주었다. 한국과학기술단체총연합회 학술 지 평가기준은 SCI, Scopus 등 국제색인 데이타베이스의 학술 지 평가기준 중 체계적인 면에서 상당부분 일치하고 있다.

\section{7. 가칭 검리사(檢理士, LBT, Laboratory Biomedicine Technologist)}

1) 한국, 일본, 대만, 미국의 보건의료 전문검사인력

본 저자들은 미국의 직급, 업무, 학제를 기준으로 우리나라 임상병리사와 동등 또는 유사하다고 생각되는 검사인력의 단체 를 구글 검색 및 미국 노동부 노동통계국 웹사이트를 통해 조사 하였다[1,7-10,21,22]. 임상병리사 등의 검사인력 명칭이 조사 대상 국가별로 원어, 영어 표기가 다르므로 가칭 검리사로 표현 한 후 학술지, 학문분야의 현황을 비교 조사하였다.

\section{2) 한국, 일본, 대만, 미국 검리사의 학술지 현황}

한국, 일본, 대만, 미국의 검리사 중에서 학술지 게재논문 (journal article)을 발간하는 단체를 대상으로 조사하였으며 핵 의학과 생리기능 분야는 제외하였다(Table 6, Figure 3). 임상 검리사 관련 단체에서 발간하는 학술지는 Korean Journal for Clinical Laboratory Science [23], Biomedical Science Letters [2], Japanese Journal of Medical Technology [7], Greater Taipei Journal of Laboratory Medicine [8], Journal of Taiwan Medical Laboratory Science [24], Clinical Laboratory Science [10]가 있으며 조직검리사 관련 단체는 Journal of Histotechnology [25]가 있으며 타직종으로 실험병 리검사기사 단체에서 발간하는 Japanese Journal of Histotechnology [26]가 있었다. 세포검리사 관련 단체에서는 학술지 
Table 6. Journals of Korea, Japan, Taiwan, and United States's laboratory biomedicine technologists (excluded nuclear medicine in vitro technologist and physiological laboratory technologist) in 2016

\begin{tabular}{|c|c|c|c|}
\hline Certification & Nation & Organization & Journal \\
\hline \multirow[t]{6}{*}{ Medical technologist } & Korea & Korean Association of Medical Technologists & $\begin{array}{l}\text { Korean Journal of Clinical Laboratory } \\
\text { Science (ISSN 2288-1662) }\end{array}$ \\
\hline & & Korean Society for Biomedical Laboratory Sciences* & $\begin{array}{l}\text { Biomedical Science Letters } \\
\text { (ISSN 2288-7415) }\end{array}$ \\
\hline & Japan & Japanese Association of Medical Technologists & $\begin{array}{l}\text { Japanese Journal of Medical Technology } \\
\text { (ISSN 2188-5346) }\end{array}$ \\
\hline & Taiwan & Taiwanese Association of Medical Technologists & $\begin{array}{l}\text { Greater Taipei Journal of Laboratory Medicine } \\
\text { (ISSN 2313-3015) }\end{array}$ \\
\hline & & Taiwan Society of Laboratory Medicine ${ }^{\dagger}$ & $\begin{array}{l}\text { Journal of Taiwan Medical Laboratory Science } \\
\text { (ISSN unknown; } 2016 \text { publication) }\end{array}$ \\
\hline & USA & $\begin{array}{l}\text { American Medical Technologists \& } \\
\text { American Society for Clinical Laboratory Science }\end{array}$ & $\begin{array}{l}\text { Clinical Laboratory Science } \\
\text { (ISSN 0894-959X) }\end{array}$ \\
\hline \multirow[t]{5}{*}{ Histotechnologist } & Korea & $\begin{array}{l}\text { Korean Society of Histotechnology and } \\
\text { Cytotechnology (in KAMT) }\end{array}$ & None \\
\hline & Japan & $\begin{array}{l}\text { Japanese Society of Histopathologic Technology } \\
\text { (formerly Japanese Society of Pathological Technology) }\end{array}$ & None \\
\hline & & Japanese Society of Histotechnology" & $\begin{array}{l}\text { Japanese Journal of Histotechnology } \\
\text { (ISSN unknown) }\end{array}$ \\
\hline & Taiwan & Taiwan Society of Pathological Technology & None \\
\hline & USA & National Society for Histotechnology & $\begin{array}{l}\text { Journal of Histotechnology } \\
\text { (ISSN 0147-8885) }\end{array}$ \\
\hline \multirow[t]{4}{*}{ Cytotechnologist } & Korea & Korean Association of Cytotechnologists (in KAMT) & None \\
\hline & Japan & Japanese Society of Cytotechnologists & None \\
\hline & Taiwan & Taiwan Society of Cytotechnologists & None \\
\hline & USA & American Society for Cytotechnology & $\begin{array}{l}\text { ASCT Journal of Cytotechnology } \\
\text { (ISSN 1095-3213; 1997-2002 ceased publication) }\end{array}$ \\
\hline \multirow[t]{4}{*}{ Genetic technologist } & Korea & None & None \\
\hline & Japan & $\begin{array}{l}\text { Japanese Association for Chromosome and } \\
\text { Gene Analysis }\end{array}$ & $\begin{array}{l}\text { Journal of the Japanese Association for } \\
\text { Chromosome and Gene Analysis } \\
\text { (ISSN 0917-8155) }\end{array}$ \\
\hline & Taiwan & None & None \\
\hline & USA & Association for Genetic Technologists & $\begin{array}{l}\text { Journal of the Association for Genetic } \\
\text { Technologists (ISSN 1523-7834) }\end{array}$ \\
\hline
\end{tabular}

${ }^{*}$ Council of professors; ${ }^{\dagger}$ Members are medical technologists and medical doctors; ${ }^{*}$ Laboratory technologist in experimental pathology. Abbreviations: ISSN, international standard serial number; KAMT, Korean Association of Medical Technologists.

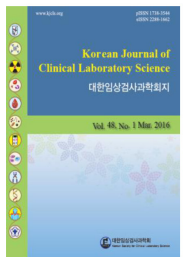

KJCLS

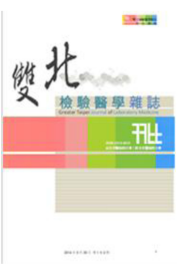

GTJLM

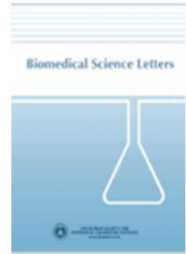

BSL

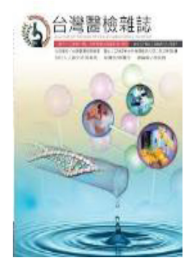

JTMLS

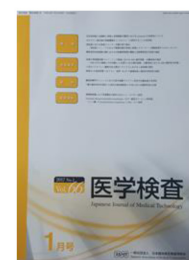

JJMT

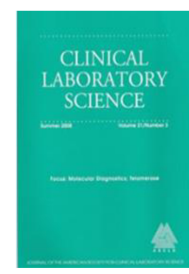

CLS

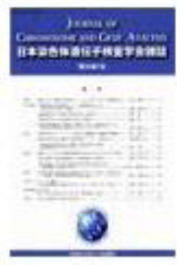

JJACGA

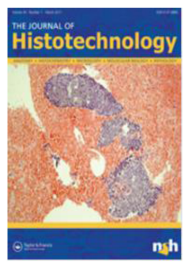

JHT

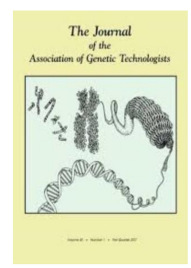

JAGT
Figure 3. Official journals by organizations for medical technologist, histotechnologist, cytotechnologist, and genetic technologist located in Korea, Japan, Taiwan, and United States. KJCLS, Korean Journal of Clinical Laboratory Science; BSL, Biomedical Sciences Letters; JJMT, Japanese Journal of Medical Technology; JJACGA, Journal of the Japanese Association for Chromosome and Gene Analysis, GTJLM, Greater Taipei Journal of Laboratory Medicine; JTMLS, Journal of Taiwan Medical Laboratory Science; CLS, Clinical Laboratory Science; JHT, Journal of Histotechnology; JAGT, Journal of the Association of Genetic Technologists.
를 발간하지 않고 있었으며 유전검리사 관련 단체는 Journal of the Japanese Association for Chromosome and Gene Analysis [27], Journal of the Association of Genetic
Technologists [28]가 있었다. Table 6와 같이 미국 검리사는 세포검사학을 제외한 임상검사학, 조직검사학, 유전검사학 관 련 학술지, 일본 검리사는 임상검사학, 유전검사학 관련 학술지 
Table 7. Identification of laboratory biomedicine technologists

\begin{tabular}{ll}
\hline \multicolumn{1}{c}{ Certification } & \multicolumn{1}{c}{ Academic area } \\
\hline Medical laboratory technologist & Medical and clinical laboratory technology (as known as Clinical laboratory science, \\
& Medical laboratory science, Biomedical laboratory science) \\
& Clinical pathologic technology* \\
Histotechnologist & Histotechnology (also called Histopathological technology) \\
Cytotechnologist & Cytotechnology \\
Genetic technologist & Clinical genetics technology \\
Nuclear medicine in vitro technologist & Nuclear medicine in vitro technology \\
Physiological laboratory technologist & Physiological laboratory technology \\
& (EKG, PF, EEG, EMG, PSG, IONM, END, TCD, Echocardiography, etc) \\
\hline
\end{tabular}

Abbreviations: EKG, electrocardiography; PF, pulmonary function; EEG, electroencephalography; EMG, electromyography; PSG, polysomnography; IONM, intraoperative neurophysiological monitoring; END, electroneurodiagnostic; TCD, transcranial doppler. *Unused name.

를 발간하고 있었으며 한국과 대만 검리사는 임상검사 관련 학 술지만 발간하고 있었다. 직종이 단일화되어 있는 한국, 일본, 대만 검리사의 경우 학술지 투고범위가 임상검사학을 중심으로 조직검사학, 세포검사학, 유전검사학, 생리기능검사학을 포함 하고 있는 것이 특징이다.

\section{3) 한국, 일본, 대만, 미국 검리사의 학문분야 현황}

검리사의 학문분야는 NAACLS (National Accrediting Agency for Clinical Laboratory Sciences), Pathpedia, Pearson edcuation, 학술단체의 인터넷 웹사이트를 검색하여 조사되었으며[29-37], 각각 업무범위에 따라서 임상검사학, 조 직검사학, 세포검사학, 유전검사학, 핵의검사학, 생리기능검사 학으로 분류하고 있었다(Table 7).

\section{8. 최다 게재논문 연구자}

창간호부터 2016년까지 학술지에 주저자(제 1저자 또는 교 신저자)로 투고한 최다 논문 게재자는 제갈승주 교수(원광보건 대학교 임상병리과)로 41편으로 조사되었다[23].

\section{9. 게재논문 분석}

협회 창설이후 발간된 학술지에 대한 논문 분석은 총 두 차례 발표되었다. 1967년부터 1984년까지 Yang 등의 연구[38]와 1985년부터 2012년까지 Koo의 연구[39]를 통해 게재논문의 연구동향을 파악할 수 있었다.

\section{0. 대한임상검사과학회지 성격}

대한임상검사과학회지는 임상병리검사학 및 관련된 생명과 학, 보건의료과학 분야의 광범위한 연구 주제를 대상으로 하고 있다. 대한임상검사과학회지의 최근 3 년간 연구 주제를 살펴보
면 임상병리 관련 논문이 $25 \%$ 를 차지한다. 이러한 사유로 대한 임상검사과학회지는 한국연구재단 학술연구분야분류에 의약 학이 아닌 자연과학으로 등록하고 있는 실정이다[16]. 2017년 7월 대한임상검사과학회 회원 현황은 500명으로 보건과학대 학 임상병리학과 교수와 보건의료기관 임상병리사로 구성되어 있다. 대한임상검사과학회의 목표는 $\mathrm{KCI}$ 를 유지하고 지금보다 더 좋은 논문을 많이 게재하여 영향력지수 0.7 이상으로 높이는 것과 우수학술지로 만드는 것이다.

\section{결 론}

대한임상검사과학회지는 1967 년 창간 이후 50 주년을 맞아 역사적 획을 긋는 전환점에 서 있다. 따라서 본 연구는 대한임상 병리사협회, 대한임상검사과학회가 추진해온 사업을 되돌아보 고 이를 바탕으로 학술지의 수준 높은 도약을 위해서 학회의 미 비점을 냉정하게 파악하여 발전방안을 제시함으로써 회원들에 게 존경받고 신뢰받는 학술지로 거듭나고자 함이다.

《첫 번째, 발전방안》으로 대한임상검사과학회지는 논문 원고에 대한 교정, 교열을 할 수 있 는 원고편집인(manuscript editor, copy editor)을 발굴 육성해야 한다. 원고편집인의 역할 은 투고논문이 게재논문으로 확정될 때 그 가치를 인정받는다. 교정, 교열은 학술지 평가에서 편집의 전문성, 논문집의 가독성, 참고문헌의 완전성, 심사의 구체성 점수를 증감시킬 수 있는 항 목으로 2016년 학술지 계속평가에서 쓰라린 경험을 한 바 있다. 즉, 투고원고의 오류를 잡아내고 양식과 형식을 국제 수준으로 맞추려면 꼼꼼하게 작업을 하는 전문가가 필요하다. 편집위원 장과 원고편집인은 국제수준의 양식과 형식 그리고 한국연구재 단 학술지평가를 비롯하여 국내외 다양한 학술지 선정 심사의 기준항목 등을 명확히 이해하고 대한임상검사과학회지가 이러 한 체계에 부합할 수 있도록 한국과학학술지편집인협의회와 대 
한의학학술지편집인협의회에서 주최하는 편집인 워크솝을 통 해서 관련사항을 지속적으로 습득해야 한다.

《두 번째, 발전방안》으로 대한임상검사과학회지는 $\mathrm{KCI}$ 등 재학술지를 지속적으로 유지해야한다. 대한임상검사과학회지 는 높은 논문 게재율, 낮은 영향력지수, 높은 자가인용지수, 낮 은 회원 관심도가 문제가 되고 있다. 대한임상검사과학회지를 위해서 수준 높고 신속한 심사를 해 주신 분들, 저명한 국내외 학 술지에 대한임상검사과학회지를 인용해 주시 분들에게 유익할 수 있도록 학술상규정도 재검토해야 할 것이다. 또한 본 학회지 의 영향력지수를 높이기 위해서 연구과제 논문, 정책과제 논문 등을 적극 유치할 필요가 있다.

《세 번째, 발전방안》으로 대한임상검사과학회지는 국제적 인용색인 데이터베이스인 SCOPUS 등재를 목표로 해야 한다. 국내외 많은 생의학계열 전문학회들은 해당 학술지를 $\mathrm{SCI}$ (science citation index: SCI Core, SCI-Expended) [40], SCOPUS [41], MEDLINE, PUBMED 등에 등재하기 위해서 필 사적으로 경쟁하고 있다[42-43]. 학술지 등재 여부는 학회에 대 한 전문성 수준, 사회적 지위를 가늠하게 하는 척도이기 때문이 다[44]. 대한임상검사과학회지를 국제적인 수준으로 높이기 위 해서는 전략적 연구주제를 발굴하고, 해외 학회 및 학자들 간에 외연을 넓이는 노력이 필요하다.

끝으로 학술지들의 발자취를 다시 짚어봄으로써 과거의 학 술지를 창간하시고 발전시켜 오신 선배님들의 노고에 감사드리 고 미래의 새로운 도약을 준비하고자 한다. 우리는 현재의 자리 에 만족하지 않고 대한임상검사과학회지의 발전과 성장을 위해 서 목표를 세우고 단계별로 노력해야 할 것이다. 질 높은 논문들 이 게재되어 학술지의 수준이 날로 향상 되고, 국민건강수준 향 상에 실질적으로 기여하게 되기를 기원한다. 그 간 학술지의 매 호 정시 발간, 심사와 편집에 헌신적 노력을 기울여 준 심사위 원, 편집위원들에게 감사드린다.

\section{요 약}

대한임상검사과학회에서 발간하는 대한임상검사과학회지 는 대한임상병리사협회의 공식 학술지이다. 2017년은 대한임 상검사과학회지의 창간 50주년 되는 해이다. 1967년 창간 시 학술지 명칭은 "대한임상병리사회지(1967년 1권 1994년 26 권)”이며 변경된 명칭은 1995년 "대한임상병리검사과학회지 (1995년 27권 2003년 35권)", 2004년 “대한임상검사학회 지” 및 2014년 “대한임상검사과학회지(2004년 36권 현재, pISSN 1788-3544, eISSN 2288-1662)”이다. 본 연구는 대한
임상검사과학회지의 발전 방안을 모색하는 데 목적이 있다. 한 국연구재단은 1998년부터 학술지 평가제도를 시작하였다. 주 요 국내 데이터베이스로는 연구재단, 과총, 의편협 등이 있고, 주요 국외 데이터베이스는 SCI Core, SCI-Extended, SCOPUS, MEDLINE, PUBMED 등이 있다. 늦은 감이 있지만, 대한임상검사과학회지는 2014년부터 한국연구재단의 한국학 술지인용색인에 등재되었다. 1,300 편 이상의 논문이 출판되었 으며 대한임상검사과학회의 발전을 위한 엄청난 공헌이 학술지 에 의해 기여를 하였다. 대한임상검사과학회지를 색인 데이터 베이스에 등재시키는 것은 직업 수준과 사회적 지위를 이해하 는 가치 척도이다. 대한임상검사과학회지는 큰 도전에 직면해 있다. 대한임상검사과학회지가 국제적으로 인정받는 저널이 되는 본래의 목표를 달성하려면 엄청난 노력이 필요하다. 궁극 적으로 대한임상검사과학회 및 대한임상병리사협회는 $\mathrm{KCI}$ 와 $\mathrm{SCOPUS}$ 와같은 데이터베이스에 등재하는 것을 목표로 설정해 야 한다.

\section{Acknowledgements: None}

Funding: None

Conflict of interest: None

\section{REFERENCES}

1. KAMT. Thirty years of the Korean Association of Medical Technologists. Korean Association of Medical Technologists: Seoul; 1992. p53, 123, 227-229.

2. KSBLS. Korean Society for Biomedical Laboratory Sciences [Internet]. Busan: Korean Society for Biomedical Laboratory Sciences; 2017 [cited 2017 April 13]. Available from: http://www.biomedsci.or.kr/

3. KCI. Korea Citation Index [Internet]. Daejeon: National Research Foundation of Korea; 2017 [cited 2017 April 13]. Available from: https://www.kci.go.kr/kciportal/main.kci

4. JSLM. Japanese Society of Laboratory Medicine [Internet]. Tokyo: Japanese Society of Laboratory Medicine; 2017 [cited 2017 April 13]. Available from: http://www.jslm.org/about /rules/pdf/teikan.pdf

5. CLMJ. College of Laboratory Medicine [Internet]. Tokyo: College of Laboratory Medicine; 2017 [cited 2017 April 13]. Available from: clmj.umin.jp/clinical/PDF/enkaku.pdf

6. IBMS. Institute of Biomedical Science [Internet]. London: Institute of Biomedical Science; 2017 [cited 2017 April 13]. Available from: https://www.ibms.org/about/ibms-history/

7. JAMT. Japanese Association of Medical Technologists [Internet]. Tokyo: Japanese Association of Medical Technologists; 2017 [cited 2017 April 13]. Available from: http://www.jamt.or. jp/books/jstage/

8. TAMT. Taiwanese Association of Medical Technologists [In- 
ternet]. Taipei: Taiwanese Association of Medical Technologists; 2017 [cited 2017 April 13]. Available from: https://www. mt.org.tw/taipeicity/periodical.php

9. AMA. American Medical Academy [Internet]. Miami: American Medical Academy; 2017 [cited 2017 April 13]. Available from: http://www.americanmedicalacademy.org/clsmt.php

10. AMT. American Medical Technologists [Internet]. Rosemont: American Medical Technologists; 2017 [cited 2017 April 13]. Available from: http://www.americanmedtech.org/GetCertified.aspx

11. ASCLS. American Society for Clinical Laboratory Science [Internet]. McLean: American Society for Clinical Laboratory Science; 2017 [cited 2017 April 13]. Available from: http:// www.ascls.org/about-us/history

12. ASCP. American Society for Clinical Pathology [Internet]. Chicago: American Society for Clinical Pathology; 2017 [cited 2017 April 13]. Available from: https://www.ascp.org/content/docs/pdf/boc-pdfs/procedures/examination-procedures.pdf?sfvrsn=12

13. AAB. American Association of Bioanalysts [Internet]. Saint Louis: American Association of Bioanalysts; 2017 [cited 2017 April 13]. Available from: https://www.aab.org/aab/Certification. asp

14. CSMLS. Canadian Society of Medical Laboratory Science. IInternet]. Hamilton: Canadian Society of Medical Laboratory Science; 2017 [cited 2017 April 13]. Available from: http:// www.csmls.org/Medical-Laboratory-Professionals/About/Wh o-are-Lab-Professionals.aspx

15. AIMS. Australian Institute of Medical Scientists. [Internet]. Milton: Australian Institute of Medical Scientists; 2017 [cited 2017 April 13]. Available from: https://www.aims.org.au/services/qualification-assessment16.

16. IFBLS. International Federation of Biomedical Laboratory Science [Internet]. Hamilton: International Federation of Biomedical Laboratory Science; 2017 [cited 2017 April 13]. Available from: http://www.ifbls.org/index.php/en/about-us/about-us-separator/background

17. NRF. National Research Foundation of Korea [Internet]. Daejeon: National Research Foundation of Korea; 2017 [cited 2017 April 17]. Available from: http://www.nrf.re.kr/biz/info/info/view?biz_no=8

18. NRF. Korea Citation Index [Internet]. Daejeon: National Research Foundation of Korea; 2017 [cited 2017 April 17]. Available from: http://www.nrf.re.kr/biz/info/info/view?biz_no=9

19. KOFST. Korean Federation of Science and Technology Societies [Internet]. Seoul: Korean Federation of Science and Technology Societies; 2017 [cited 2017 April 17]. Available from: https://www.kofst.or.kr/

20. KAMJE. Korean Association of Medical Journal Editors [Internet]. Seoul: Korean Association of Medical Journal Editors; 2017 [cited 2017 April 17]. Available from: https://www.kamje.or.kr/

21. BLS. US Bureau of Labor Statistics [Internet]. Washington DC: US Bureau of Labor Statistics; 2017 [cited 2017 May 01]. Available from: https://www.bls.gov/ooh/healthcare/home.htm

22. Cho KJ, Lee CK, Lee SK, Chung SW, Kim TU, Moon HJ, et al. A study on certifying systems for clinical laboratory scientists. J Educ Eval Health Prof. 2004;1(1):51-66.
23. KSCLS. Korean Society for Clinical Laboratory Science [Internet]. Seoul: Korean Society for Clinical Laboratory Science; 2017 [cited 2017 April 13]. Available from: https:// www.kjcls.org/journal/archives.html

24. TSLM. Taiwan Society of Laboratory Medicine [Internet]. New Taipei: Taiwan Society of Laboratory Medicine; 2017 [cited 2017 April 13]. Available from: http://www.labmed.org. tw/Bjournal01.asp

25. NSH. National Society for Histotechnology [Internet]. Columbia, MD: National Society for Histotechnology; 2017 [cited 2017 April 13]. Available from: http://nsh.org/content/scope-journal-histotechnology

26. JAH. Japanese Association of Histotechnology [Internet]. Tokyo: Japanese Association of Histotechnology; 2017 [cited 2017 April 13]. Available from: http://www.jah.jpn.org/new/journal/journal.html

27. JACGA. Japanese Association for Chromosome and Gene Analysis [Internet]. Tokyo: Japanese Association for Chromosome and Gene Analysis; 2017 [cited 2017 April 13]. Available from: http://www.jacga.jp/post/category/\%E5\%AD\%A6\%E4\%BC\%9A\%Е9\%9B\%91\%Е8\%AA\%8C

28. AGT. Association of Genetic Technologists [Internet]. Oceanside, CA: Association of Genetic Technologists; 2017 [cited 2017 April 13]. Available from: http://www.agt-info.org/publications/Pages/default.aspx

29. NAACLS. National Accrediting Agency for Clinical Laboratory Sciences [Internet]. Des Plaines: National Accrediting Agency for Clinical Laboratory Sciences; 2017 [cited 2017 May 01]. Available from: https://www.naacls.org/about.aspx

30. Pathpedia. Pathology and related organizations [Internet]. Saint Louis: Pathpedia; 2017 [cited 2017 April 01]. Available from: http://www.pathpedia.com/Meetings/Organizations.aspx

31. Pearson. Pearson clinical laboratory science series [Internet]. London: Pearson education; 2017 [cited 2017 April 01]. Available from: http://www.mypearsonstore.com/bookstore/ index.asp?st=56736

32. TCPTA. Taiwan Clinical Physiology Technical Association [Internet]. Taichung: Taiwan Clinical Physiology Technical Association; 2017 [cited 2017 May 01]. Available from: http://twtcpta.org/tw/

33. JSNMT. Japanese Society of Nuclear Medicine Technology [Internet]. Osaka: Japanese Society of Nuclear Medicine Technology; 2017 [cited 2017 May 01]. Available from: http://www.jsnmt.umin.ne.jp/contents/english/journuls.htm

34. Ali NI. A novel role of nuclear medicine in vitro technology in pregnancy. 1st ed. Saarbrucken: Lambert academic publishing; 2011.

35. ASCT. American Society for Cytotechnlogy [Internet]. Wake: American Society for Cytotechnlogy; 2017 [cited 2017 May 01]. Available from: http://www.asct.com/content/profession-cytotechnology

36. JSHT. Japanese Society of Histopathologic Technology [Internet]. Tokyo: Japanese Society of Histopathologic Technology; 2017 [cited 2017 May 01]. Available from: http://www. sasappa.co.jp/jsht/

37. TSPT. Taiwan Society of Pathological Technology [Internet]. Taipei: Taiwan Society of Pathological Technology; 2017 [cited 
2017 May 01]. Available from: www.facebook.com/TWPaTec/

38. Ryang YS, Kim HE, Ryu PY. Bibliographic analysis of the Korean Journal of Medical Technologists. Korean Journal of Medical Technologists. 1985;17:6-13.

39. Koo BK. Analysis of research papers published in the Korean Journal of Clinical Laboratory Science from 1985 to 2012. Korean J Clin Lab Sci. 2013;45(4):180-187.

40. Thomson Reuters. Clarivate analytics [Internet]. New York: Thomson Reuters; 2017 [cited 2017 April 01]. Available from: http://ip-science.thomsonreuters.com/cgi-bin/jrnlst/jlsubcatg.cgi? $\mathrm{PC}=\mathrm{D}$
41. Elsevier. SCImago journal and country rank [Internet]. Amsterdam: Elsevier; 2017 [cited 2017 April 01]. Available from: http://www.scimagojr.com/journalrank.php

42. Huh S. How to add a medical journal to international indexing databases? Korean J Obes. 2013;22(4);205-211.

43. Hun S. New horizon of the medical society journal published in Korea. Korean Journal of Medicine. 2009;76(3):249-251.

44. Kim SJ. An effective way to the international distribution of Korean medical and life science journals. J Korean Soc Lib Inf Sci. 2006;40(2):457-480. 